Article

\title{
Improving Fermentation Rate during Use of Corn Grits in Beverage Alcohol Production
}

\author{
Deepak Kumar ${ }^{1}$, Anna-Sophie Hager ${ }^{2}$, Alberto Sun ${ }^{2}$, Winok Debyser ${ }^{2}$, \\ Bruno Javier Guagliano ${ }^{2}$ and Vijay Singh ${ }^{1, *}$ \\ 1 Agricultural and Biological Engineering, University of Illinois at Urbana-Champaign, Urbana, IL 61801, \\ USA; kumard@illinois.edu \\ 2 Anheuser-Busch InBev nv/sa, Brouwerijplein 1, 3000 Leuven, Belgium; \\ Sophie.Hager@AB-Inbev.com (A.-S.H.); Alberto.Sun@AB-Inbev.com (A.S.); \\ Winok.Debyser@ab-inbev.com (W.D.); brunoguagliano@hotmail.com (B.J.G.) \\ * Correspondence: vsingh@illinois.edu; Tel.: +1-217-333-9510
}

Received: 12 December 2018; Accepted: 29 December 2018; Published: 11 January 2019

check for updates

\begin{abstract}
Corn grits are commonly used adjuncts in the brewing industry in the United States, especially for lager beers. The major challenge of using a high amount of adjuncts in the brewing process is reduced levels of nutrients available to yeast during fermentation, which negatively affects the growth and functioning of yeast, and results in sluggish fermentation. The problem is usually addressed by adding external nutrition. The objective of this work was to assess the suitability of corn components other than brewer's grits to improve the fermentation rates. Water obtained after soaking of corn germ, a vital source of lipids and soluble proteins, was investigated as a source of nutrient during brewing of 40:60 (w/w) corn grits and malt mixture. Performance of water-soluble nutrients from germ of two corn verities, yellow dent corn and flint corn, was investigated. Germ soak water was added during corn grits slurry formation before mashing. The addition of germ water increased the free amino nitrogen levels by $37 \%$ and Zn concentrations by 3.6 times in the wort, which resulted in up to a $28 \%$ higher fermentation rate (between 48 to $72 \mathrm{~h}$ of fermentation) and shortened the fermentation time from 120 to $96 \mathrm{~h}$. The use of water obtained from the soaking of flint corn germ resulted in a similar shortening of fermentation time. In another approach, nutrient-rich concentrated germ soak water was directly added into the wort, which also resulted in similar improvements in the fermentation rate as those from adding germ soak water during slurry formation. Due to leaching of micronutrients and soluble proteins, the oil concentrations in the germ increased by more than $30 \%$, enhancing its economic value.
\end{abstract}

Keywords: beer; adjuncts; fermentation rate; germ; nutrient; FAN

\section{Introduction}

Beer is the oldest and the most popular alcoholic beverage in the world. Since ancient times, barley has been the most common raw material used for beer brewing. The use of barley provides advantages of easy germination, high starch content, moderate protein content, high amylolytic activity, and wort filtration assistance from husk [1,2]. However, due to increasing demands of sensory modification and specialty beers, and cost optimization, brewing industries are increasing the use of locally available less expensive unmalted grains, known as adjunct grains, in the beer brewing process [3-5]. The use of locally available grains as adjuncts in the brewing process reduces the need for importing malt, provides tax benefits (avoidance of malt tax in some countries), reduces the carbon footprint, and supports local farmers [6]. Corn, wheat, rice, unmalted barley, oats, and sorghum are some of the major adjunct grains used. High amounts of adjuncts are used to produce specialty 
beers. A type of beer known as "happoshu" is produced in Japan that contains more than $75 \%$ rice as adjuncts [6]. The use of adjuncts also provides advantages of increased foam stability, various color and flavor options, and health benefits (e.g., reduced gluten levels). The potential cost savings are highly dependent on the type of adjunct used, local prices of adjunct grains, malt availability, and other costs of productions [4]. Although the benefits of adjuncts have been realized and highlighted in the last few years only, the use of adjuncts is as old as beer itself. For example, the Sumerians (Mesopotamia; Lady Pu-Abi Queen of Ur (2600BC)) had a beer that was made from barley and emmer (ancient wheat). Raw wheat has been used as an adjunct in the production of lambic (a type of spontaneous fermented beer), in Belgium for centuries. Currently, $85 \%$ to $90 \%$ of all of the beer in the world is produced with adjuncts used in the process [5].

Due to large availability, corn grits are the most commonly used adjuncts in the United States, especially for lager beers. The use of $30 \%$ corn grits as adjuncts can reduce brewing costs by about $8 \%$ [4]. In addition to ready availability and lower cost, the use of corn adjuncts provides benefits in the form of color adjustments and sweet and fuller flavor profile. The profile of fermentable sugars and dextrins from enzymatic conversion corn-based adjuncts is similar to that of malt [2]. In 2017, about 150 million bushels of corn were used in beverage alcohol production in the United States [7].

The use of adjuncts in brewing also has several disadvantages, including the need of a cereal cooker, low enzymatic power, and reduced levels of nutrients for yeast. A cereal cooker is needed for starch gelatinization and commercial enzymes are often used to overcome the limitation of lower amylolytic activity [4]. The major limitation that use of adjuncts in the brewing process leads to is the reduced levels of nutrients available to yeast during fermentation. Most of the adjuncts used in the industry have relatively low protein levels, and replacement of malt with these adjuncts decreases the concentrations of nitrogen-containing substances during fermentation, also known as protein dilution in wort [5]. Nitrogen is an essential element required for yeast growth and synthesis of cellular proteins and other cell compounds. Individual amino acids, small peptides, and some ammonium ions produced from the proteolysis of proteins in barley malt are the main nitrogen sources for yeast metabolism in wort [8]. Free amino nitrogen (FAN) level, collectively accounting for individual amino acids and small peptides (dipeptides and tripeptides), are commonly monitored to ensure efficient yeast cell growth in order to achieve a desirable fermentation performance [8]. Poreda et al. (2013) reported that even with similar protein content in malt and corn grits, FAN concentration in wort obtained with the addition of $20 \%$ grits was $7 \%$ lower (223 ppm vs. $240 \mathrm{ppm}$ ) compared to pure malt wort [4]. It has been reported that proteins in adjuncts do not get hydrolyzed as efficiently as malt protein and result in a deficiency of total soluble nitrogen in wort [4,9]. Partially hydrolyzed proteins remain insoluble and are separated along with spent grains during filtration [5]. Other than reduced free nitrogen levels, the use of high amounts of adjuncts also decreases the concentrations of other nutrients, such as inorganic ions and vitamins, which required for efficient yeast growth [10]. The nitrogen limitation and deficiency of micronutrients results in poor yeast viability, which leads to retarded or sluggish fermentation $[5,11]$. To overcome this issue, the wort obtained during the use of high percentage of adjuncts is usually supplemented with external nutrients in order to achieve an efficient fermentation. The challenge of inefficient fermentation due to lack of yeast nutrition has also been reported in the form of the use of dry-fractionated corn for fuel ethanol production [12,13]. During whole corn fermentation, germ is a vital source of lipids and water-soluble proteins, which help in maintaining the membrane integrity and yeast performance. However, flaking grits and brewer grits, obtained from the dry-fractionation of corn, do not contain the germ fraction and have a relatively small amount of protein, oil, and other micronutrients, compared to whole corn, which causes nutrient deficiency to yeast during fermentation. The addition of yeast extract, lipid supplementation, and leaving some germ (minimum 20\%) behind, are some successful reported approaches to improving fermentation of dry-fractionated corn during fuel ethanol production [12-14]. However, due to concerns of the negative effects of lipids on beer flavor and foam, these approaches cannot be applied in the beverage alcohol production process. One approach that could have potential application in the brewing process 
is the extraction of soluble nutrients from corn germ by soaking and the use of that water in the process. The water would contain only soluble proteins and micronutrients but not lipids. Murthy et al. (2006) reported that the use of germ soak water ( $2 \mathrm{~h}$ soaking) in the dry grind process resulted in higher final ethanol concentrations $(14.7 \%$ vs. $12.3 \%(\mathrm{v} / \mathrm{v}))$ with a relatively small amount of residual glucose [14]. Juneja et al. (2018) reported that the use of water from germ soaked for a longer time (12 $\mathrm{h}$ instead of $2 \mathrm{~h}$ ) can result in complete fermentation (no residual glucose) and achieve a fermentation profile similar to that obtained with the addition of excess B vitamins or protease enzymes [15]. Both of these studies only reported the fermentation improvements but did not determine the actual nutrition enhancement with the addition of germ soak water.

The objective of this study was to investigate the feasibility of using corn germ soak water to improve yeast nutrition and fermentation rates in the brewing process using $40 \%$ corn grits adjuncts. Performance of water-soluble nutrients from germ of two corn verities, yellow dent corn and flint corn, was investigated. In addition to a new process development, individual amino acids, total FAN levels, and other important nutrients (e.g., Zn concentrations) in the germ water and wort were determined to enhance the understanding of the potential benefits of implementing this approach.

\section{Materials and Methods}

\subsection{Materials}

Degermed yellow brewing grits and corn germ (from yellow dent corn) samples were obtained from a commercial corn dry milling plant (Bunge, Danville, IL, USA). Malt and flint corn samples were obtained from a commercial brewing company (Anheuser-Busch InBev, Brouwerijplein 1, 3000 Leuven, Belgium). Germ from the flint corn was separated using a $1 \mathrm{~kg}$ laboratory scale protocol outlined by Rausch et al. (2009) [16]. All materials were stored at $4{ }^{\circ} \mathrm{C}$ in refrigerator until use.

Active dry brewing yeast Saflager S-189 yeast, used for the fermentation in the current study, was obtained from the Fermentis-Lesaffre Yeast Corporation (Milwaukee, WI, USA). Novozymes (Bagsvaerd, Denmark) generously donated Termamyl $120 \mathrm{~L}$, Type L, a thermostable bacterial $\alpha$-amylase preparation.

\subsection{Corn Grits and Germ Composition}

Starch content in the ground corn grits was determined by the modified acid hydrolysis method [17] and was found to be $79.64 \%$. About $1 \mathrm{~g}$ of ground corn grits were mixed with $50 \mathrm{~mL}$ of $0.4 \mathrm{~N} \mathrm{HCl}$ in 100-mL autoclavable glass bottles. After mixing, the slurry was autoclaved for $1 \mathrm{~h}$ at $126^{\circ} \mathrm{C}$ in a laboratory scale autoclave (Napco Model 9000D, Thermo Fisher 157 Scientific, Waltham, MA, USA). Glucose recovery factors were determined using pure glucose and starch samples. After cooling, 1-mL aliquot samples were withdrawn and centrifuged at $1500 \times g$ for $5 \mathrm{~min}$ (Model 5415 D, Brinkmann-Eppendorf, Hamburg, Germany). The supernatants were analyzed in the HPLC for glucose concentration determination.

Germ (before and after soaking) samples were analyzed for oil (AOAC method 920.39) content by a commercial analytical laboratory (Illinois crop improvement association, Champaign, IL, USA) [18]. All analyses were conducted in duplicates.

\subsection{Brewing Process}

A simple schematic of the lab-scale process used for the beverage alcohol production is shown in Figure 1. Corn grits and malt samples were ground in a hammer mill (model MHM4, Glen Mills, 126 Clifton, NJ, USA) equipped with a 1.0-mm sieve. The moisture contents of the ground samples were determined by drying flour at $135^{\circ} \mathrm{C}$ for $2 \mathrm{~h}$ (Approved Method 44-19, AACC International 2000). 


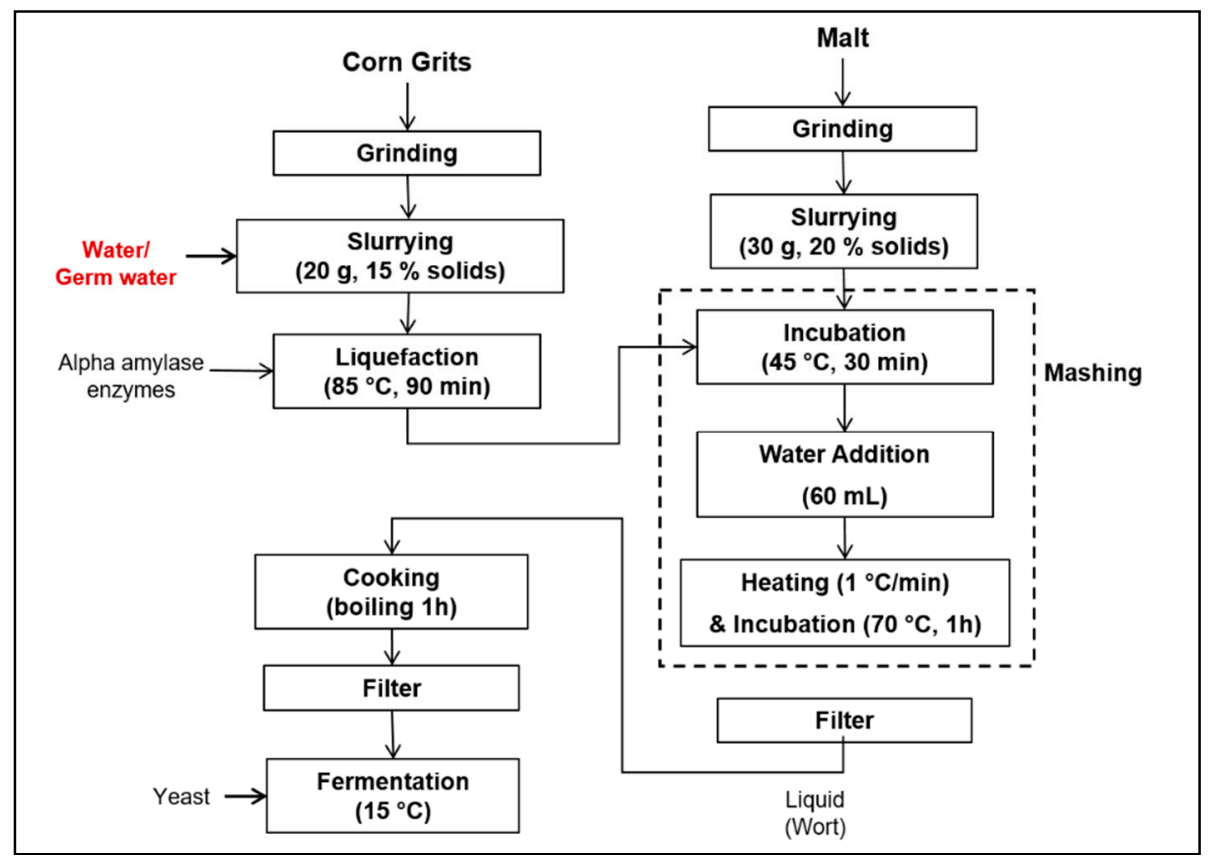

Figure 1. Schematic of steps followed for fermentation of corn grits and malt.

Malt and corn grits were used in 60:40 ratios on a mass basis. Twenty grams (dry weight) of ground corn grits was mixed with a calculated amount of deionized water (for control) or germ soak water (for treatments) to form a slurry with $15 \%$ solids, and the $\mathrm{pH}$ of the slurry was adjusted to 5.8 (recommended optimum $\mathrm{pH}$ for the $\alpha$-amylase). Germ soak water was obtained by soaking the germ in deionized water (1:10, germ:water on a weight basis) at $52{ }^{\circ} \mathrm{C}$ for $12 \mathrm{~h}$, with continuous shaking at $125 \mathrm{rpm}$. After soaking, the liquid was vacuum-filtered through Whatman No. 4 filter paper and used to make corn slurry. The corn grits starch was liquefied by adding $10 \mu \mathrm{L}$ of $\alpha$-amylase and agitating the slurry at $85^{\circ} \mathrm{C}$ for $120 \mathrm{~min}$ using an infrared heated reactor system equipped with mini-stainless steel tubular reactors that are locked onto a rotating carrousel (Labomat BFA-12, Werner Mathis AG, Switzerland). Simultaneously, $30 \mathrm{~g}$ (dry weight) of ground malt was mixed with a calculated amount of deionized water to form a mixture with $20 \%$ solids, and incubated at $45^{\circ} \mathrm{C}$ for $30 \mathrm{~min}$, with continuous shaking at $125 \mathrm{rpm}$. After incubation, malt slurry was mixed with the liquefied corn slurry (cooled to $\left.45^{\circ} \mathrm{C}\right)$, and $60 \mathrm{~mL}$ of preheated water $\left(45^{\circ} \mathrm{C}\right)$ was added in the mixture. The mixture was heated to $70{ }^{\circ} \mathrm{C}$ at the heating rate of $1{ }^{\circ} \mathrm{C}$ per minute, and incubated for $60 \mathrm{~min}$ in the mini-stainless steel tubular reactors using a Labomat incubator. The mash was cooled down to room temperature and filtered using Whatman No. 4 filter paper to separate liquid (wort) and solids (spent grains). The filtered wort was boiled on a heating plate for about $1 \mathrm{~h}$ and filtered again (using Whatman No. 4 filter paper) after cooling. Yeast inoculum was prepared by sprinkling dry yeast in ten times the amount of water and incubating at $23{ }^{\circ} \mathrm{C}$ for $20 \mathrm{~min}$, followed by gentle stirring for $30 \mathrm{~min}$. The yeast was inoculated in the wort at the dosage of $100 \mathrm{~g} / \mathrm{hL}$, as recommended by the supplier. The fermentation was performed at $15^{\circ} \mathrm{C}$ for $144 \mathrm{~h}$ with continuous agitating at $125 \mathrm{rpm}$. About $2 \mathrm{~mL}$ of samples were withdrawn every $24 \mathrm{~h}$ to monitor the fermentation.

\subsection{Sample Analysis and Ethanol Production Rate}

Samples collected during the fermentation process were analyzed for sugars and ethanol concentrations using HPLC, equipped with an ion-exclusion column (Aminex HPX-87H, Bio-Rad, Hercules, CA, USA). The mobile phase used was $50 \mathrm{mM}$ sulfuric acid, eluted at $50{ }^{\circ} \mathrm{C}$ and $0.6 \mathrm{~mL} / \mathrm{min}$. The amounts of sugars and ethanol were quantified using a refractive index detector and calibration based on pure sugars and ethanol standards. 
Ethanol production rates (fermentation rates, $\% \mathrm{v} / \mathrm{v}-\mathrm{h}$ ) between different time points were calculated using the following equation.

$$
\text { Ethanol production rate }=\frac{E_{t 2}-E_{t 1}}{t_{2}-t_{1}}
$$

where $E_{t 2}$ and $E_{t 1}$ are ethanol concentrations $(\% \mathrm{v} / \mathrm{v})$ at fermentation times $t_{2}$ and $t_{1}$ in hours.

\subsection{Total Free Amino Nitrogen and Amino Acid Profile}

Total free amino nitrogen (FAN) concentrations in various germ soak water samples were determined using the ninhydrin colorimetric method (Official Method 945.30L, AOAC 1980) [19]. Quantification of individual amino acids concentration in germ soak water and wort was conducted at the University of Missouri Agricultural Experiment Station Chemical Laboratories (ESCL) using the AOAC official methods (Method 982.30 E(a,b)) [20].

\subsection{Zinc Determination}

Zn concentrations in the germ water samples were determined using ICP (Inductively Coupled Plasma) analysis, performed in the Microanalysis Laboratory, School of Chemical Sciences at the University of Illinois.

\section{Results and Discussion}

\subsection{Effect of Germ Water Addition}

The wort obtained from the processing of a mixture of malt and corn grits (60:40, weight basis) as described in Figure 1, contained 1.1\% glucose, $8 \%$ maltose, $1.5 \%$ maltotriose, and $0.25 \%$ fructose. The sugar concentrations were similar in wort obtained from control samples (no germ water addition) and wort from germ water supplemented mash. The sugar profile and concentrations from the current process match closely with the values reported by Stewart et al. (2013) for 30\% corn adjunct wort [10]. Figure 2 illustrates the comparison of ethanol concentration during fermentation, for control and germ water addition. Use of germ soak water improved the fermentation profile significantly compared to that of the control. Yeast preferred glucose over maltose during fermentation, and almost all of the glucose was consumed in the first $48 \mathrm{~h}$ for both cases (Figure 3). Fermentation profiles of control and germ soak water samples were almost similar in the first $48 \mathrm{~h}$ (until the presence of glucose). However, maltose to ethanol conversion rates were higher for samples with the addition of germ soak water. Almost all of the maltose was converted to ethanol in $96 \mathrm{~h}$ for the germ soak water samples, compared to $1.47 \%(\mathrm{w} / \mathrm{v})$ residual maltose for the control. The ethanol concentration of $6.32 \%(\mathrm{v} / \mathrm{v})$ was $18.5 \%$ higher compared to the control $(5.33 \%(\mathrm{v} / \mathrm{v}))$ after $96 \mathrm{~h}$ of fermentation. Ethanol production rates for the germ water treatment were $16 \%$ and $28 \%$ higher than that of control between $24-48$ and $48-72 \mathrm{~h}$ of fermentation, respectively. Due to low sugar availability, fermentation rate drops after $72 \mathrm{~h}$ and it was lower for the germ water treatment compared to the control after $96 \mathrm{~h}$ of fermentation. The higher fermentation rate could be attributed to the improved functioning of the yeast due to the availability of free amino acids and other nutrients present in germ soak water.

Total FAN concentrations found in the water obtained from germ soaked in various amounts of water (germ:water weight ratios of 1:10, 1:5, 1:2.5) are presented in Table 1. As discussed earlier, the brewing industry uses FAN concentration as an indicator of available assimilable nitrogen. Free amino nitrogen is essential for the synthesis of structural proteins and enzymatic proteins required for yeast growth and metabolic reactions [5]. Adequate levels of FAN are critical for the yeast to perform efficient fermentation $[8,21]$. FAN is considered an index for predicting yeast viability, vitality, and fermentation efficiency [10]. Water obtained from 1:10 germ:water (weight basis) ratio, used in this experiment, contained $127 \mathrm{ppm}$ of FAN. The use of this water to make corn mash resulted in total FAN of $170 \mathrm{ppm}(11.5 \mathrm{mg} / \mathrm{L} /$ Plato $)$ in the wort, compared to $125 \mathrm{ppm}(8.4 \mathrm{mg} / \mathrm{L} /$ Plato $)$ in wort from 
the control. Heldt-Hansen et al. (2011) recommended a FAN concentration of 9-14 mg/L/Plato and $10-18 \mathrm{mg} / \mathrm{L} /$ Plato in unmalted barley (adjuncts) wort and all-malt worts, respectively, to achieve comparable fermentation performance [5]. The FAN level in the wort with the use of germ soak water is within the recommended range. The FAN concentrations in the germ water increased with a decrease in water used while soaking. As the amount of soaking water was reduced to half (1:5 germ:water ratio), the FAN concentrations almost doubled. Similarly, for a 1:2.5 germ:water ratio, the FAN concentration was more than 4 times that of water compared to the treatment with 1:10 germ:water soaking (Table 1). The effect of shaking during the germ soaking on FAN concentrations was also investigated. No significant difference in FAN concentrations in the water obtained from germ soaked with or without shaking was observed.

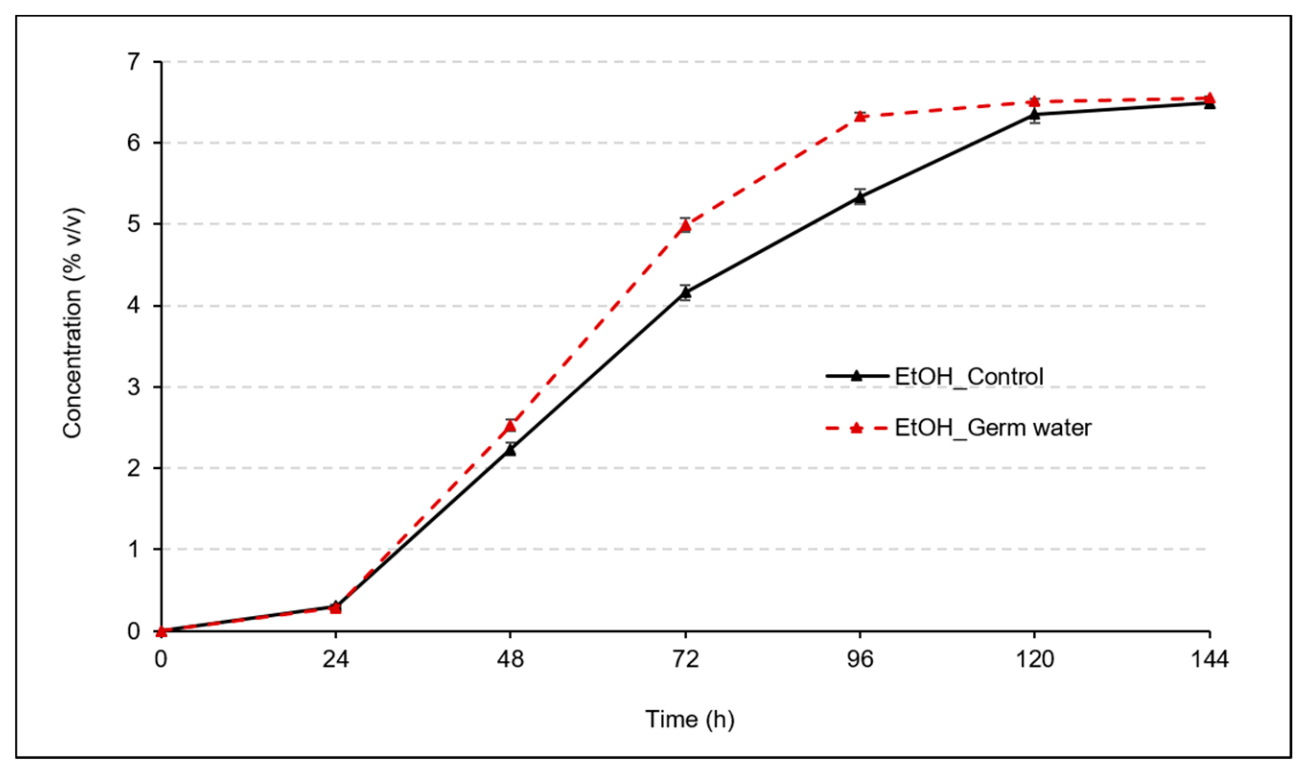

Figure 2. Ethanol concentration during fermentation without (control) and with addition of germ soak water.

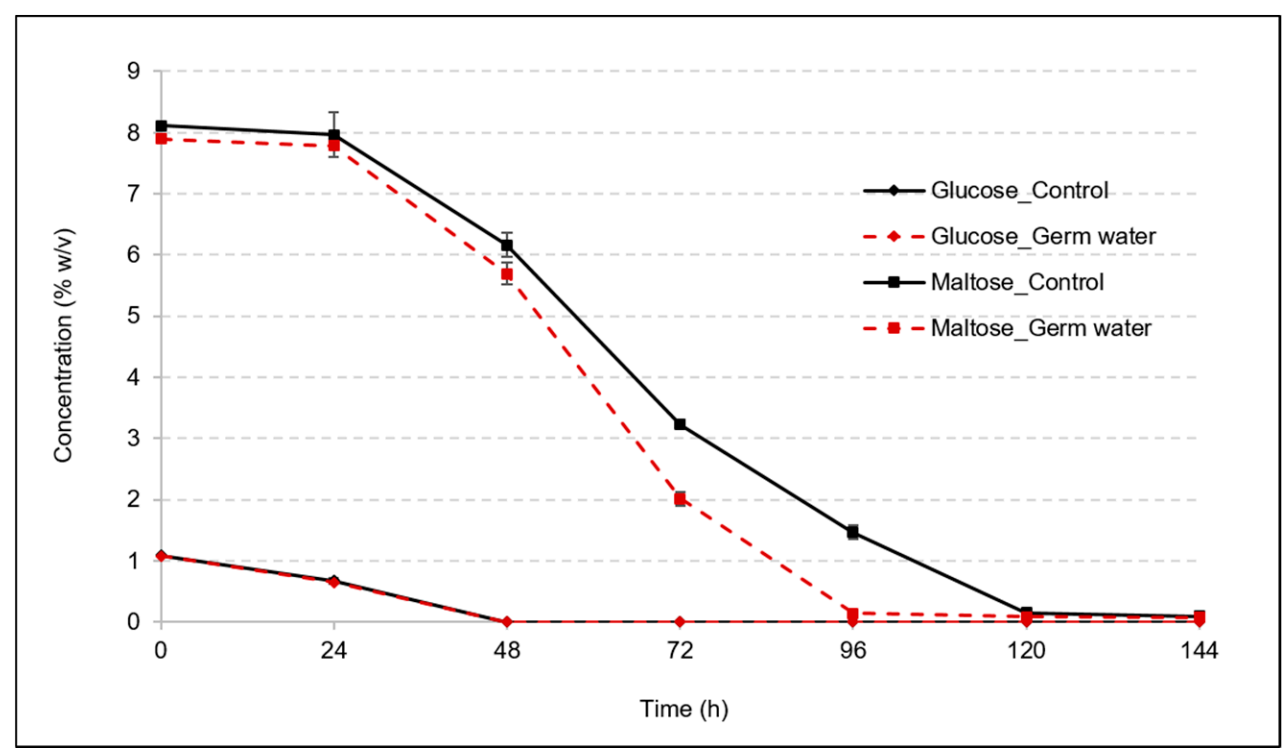

Figure 3. Glucose and maltose concentration during fermentation without (control) and with addition of germ soak water. 
Table 1. Free amino nitrogen (FAN) concentrations in the water obtained from germ soaked under various conditions.

\begin{tabular}{cc}
\hline Soaking (Germ:Water by Weight) & Concentration (ppm) \\
\hline $1: 10$ & $127 \pm 8$ \\
$1: 5$ & $250 \pm 12$ \\
$1: 2.5$ & $517 \pm 12$ \\
\hline
\end{tabular}

Other than reducing overall free nitrogen levels, the use of adjuncts is believed to alter the proportion of the various amino acids in the wort, which is also important for yeast functioning [5]. Figure 4a illustrates the concentration of amino acids in the germ water. Correspondingly, the amino acid concentrations for wort from control and germ water supplemented samples are provided in Figure $4 \mathrm{~b}$. Total amino acid concentrations in germ water, wort from control, and wort from germ water supplemented samples were found to be 100 ppm, 115 ppm, and 146 ppm, respectively. The concentrations of lysine and leucine, amino acids categorized in Group A (fast absorption) and Group B (intermediate absorption), were double for wort in germ water supplemented samples compared to wort from control samples. Other than these, the amounts of phenylalanine and hydroxylysine were also double in wort from germ water supplemented samples.

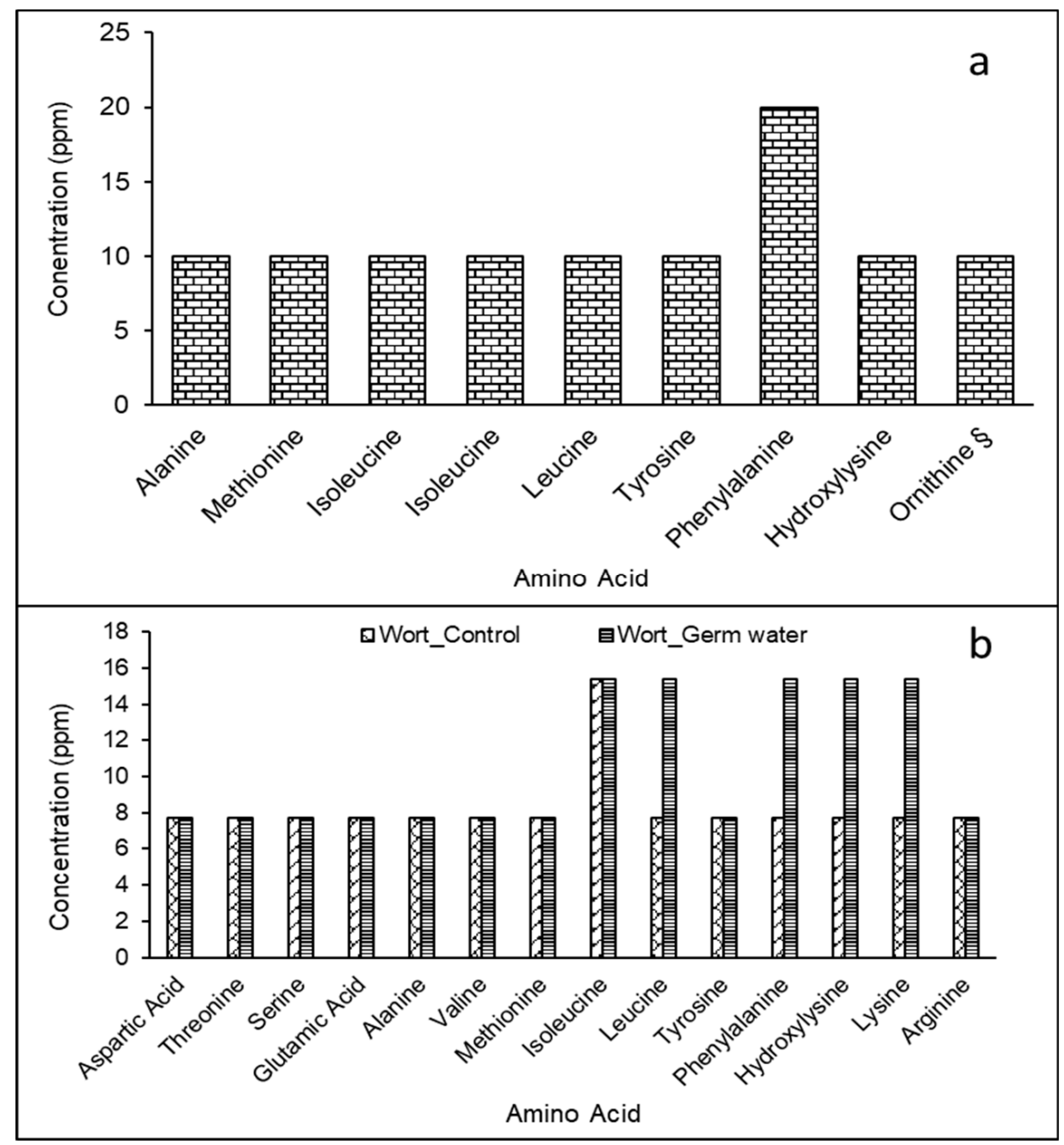

Figure 4. Amino acid concentrations in (a) liquid obtained after germ soaking and (b) wort from wort obtained from control samples and from germ water supplemented samples. Data in Figure 4a is average of two replications. 
Other than FAN, some trace metals-such as Zn, which is considered to be an important trace metal that plays an essential structural and functional role in yeast cells-act as a modulator of environmental stress and are important for the fermentation process [22,23]. Although $\mathrm{Zn}$ concentrations are at a sub-ppm level in the wort, even these small amounts are critical for efficient fermentation of wort [24]. Zinc concentrations below $0.1 \mathrm{ppm}$ can lead to fermentation problems, especially decreased specific rate of fermentation [24,25]. The germ water used in this experiment (from 1:10 germ:water ratio) contained $1.49 \mathrm{ppm}$ of $\mathrm{Zn}$. The use of this water in the brewing process resulted in a $\mathrm{Zn}$ concentration of $0.33 \mathrm{ppm}$ in the wort, compared to $0.09 \mathrm{ppm}$ in wort from the control. The adequate levels of $\mathrm{Zn}$ in the wort from the germ water supplemented process can be another factor for the observed increased fermentation rates.

\subsection{Effect of Germ Water Addition from Flint Corn Germ}

For real application of this approach (using water-soluble nutrients from corn germ) in the brewing industry, it is critical to ensure the availability of the nutrient source. As the types of corn used vary among industries, it was important to investigate the performance of germ obtained from various corn types. The effect of water obtained from the soaking of germ from the fractionation of flint corn was also investigated on the fermentation performance of lager yeast. Germ was separated from the flint corn milled employing a slightly adapted laboratory-scale $(1 \mathrm{~kg})$ dry-milling procedure, outlined by Rausch et al. (2009). About 40 to $50 \mathrm{~g}$ of germ was obtained from the milling of $1 \mathrm{~kg}$ of corn. Germ water collection and fermentation procedures were similar to that performed with the yellow dent corn germ. Sugar consumption and ethanol production profiles during the fermentation are presented in Figure 5. Similar to the case of yellow dent corn germ, the use of water from the soaking of flint corn germ improved the fermentation of maltose significantly compared to that of the control. The fermentation profiles of the control and germ soak water samples were almost similar in the first $48 \mathrm{~h}$, until all of the glucose was consumed. The ethanol production rate for the germ water treatment was $16 \%$ and $42 \%$ higher than the control between $24-48$ and $48-72 \mathrm{~h}$ of fermentation, respectively. Almost all of the maltose and maltotriose were consumed in $96 \mathrm{~h}$ of fermentation in the case of germ soak water treatment contrary to $1.31 \%$ and $0.38 \%(\mathrm{w} / \mathrm{v})$ residual maltose and maltotriose, in the case of control. Due to low sugar availability, the fermentation rate dropped and was lower than the control after $72 \mathrm{~h}$ and it was almost zero after $96 \mathrm{~h}$ of fermentation. Although all the maltose was consumed in $96 \mathrm{~h}$ in both cases, the increase in fermentation rate between $48-72 \mathrm{~h}$ in the current case was compared to that observed with the addition of water obtained from yellow dent corn germ $(42 \%$ vs. $28 \%$ increase). This could be due to the availability of relatively higher free nitrogen. Water obtained from the soaking of flint corn germ at 1:10 germ:water (weight basis) ratio contained 195 ppm of FAN, which was significantly higher than the water from dent corn germ (127 ppm). The total FAN concentration in wort with the use of flint corn germ was 193 ppm (13.1 mg/L/Plato), compared to 128 ppm (8.7 $\mathrm{mg} / \mathrm{L} /$ Plato $)$ in the control of this experiment, and $170 \mathrm{ppm}(11.5 \mathrm{mg} / \mathrm{L} /$ Plato $)$ in wort from the addition of yellow dent corn germ. The relatively higher amount of FAN in the water from flint corn germ compared to dent corn germ could be due to genetic differences between two corn verities and different quality germ obtained from laboratory scale milling (for flint corn) and commercial milling (for dent corn). The high quality of the flint corn germ was also indicated by higher oil (28.8 vs. $21.6 \%$, dry basis) and protein ( $17.3 \%$ vs. $15.5 \%$, dry basis) contents in the flint corn germ compared to the yellow dent corn germ. 


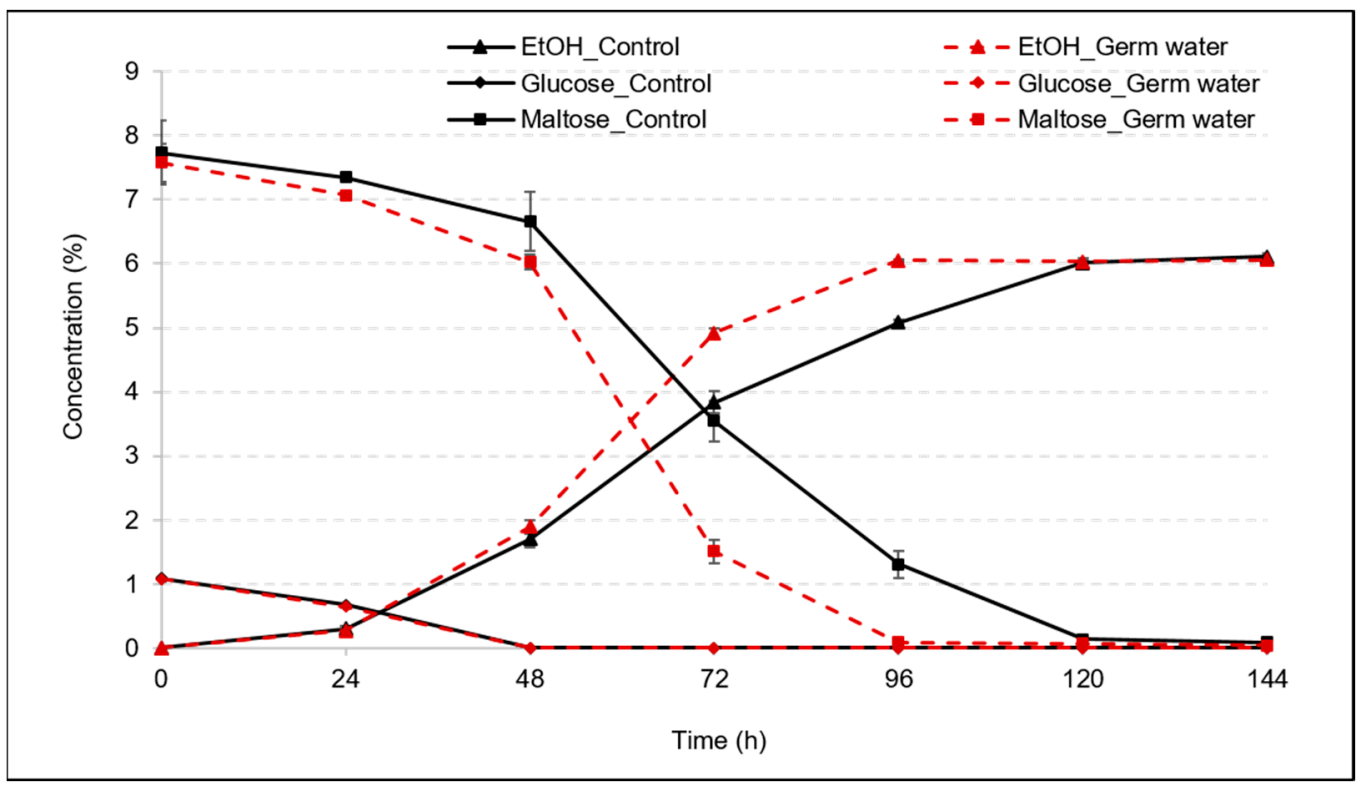

Figure 5. Ethanol $(\% \mathrm{v} / \mathrm{v})$, glucose $(\% \mathrm{w} / \mathrm{v})$, and maltose $(\% \mathrm{w} / \mathrm{v})$ concentrations during fermentation without (control) and with the addition of flint corn germ soak water.

\subsection{Use of Concentrated Germ Water in Wort}

In the previous experiments, germ water was added during the slurry formation before mashing (Figure 1). To explore the possibility of using these water-soluble nutrients without making many changes in the currently used brewing process, another approach of adding germ water directly in the wort was also investigated. However, the addition of germ water in wort would result in dilution. To provide the same amount of nutrients (as in previous experiments), the addition of germ water (1:10 germ to water ratio soaking) would result in about $40 \%$ dilution. This problem was addressed by using germ soak water containing a higher concentration of nutrients. The total FAN in the water obtained from 1:2.5 germ to water ratio (referred as $4 \mathrm{X}$ water in the manuscript) was a little more than 4 times the FAN concentration in water from 1:10 germ to water ratio (referred as $1 \mathrm{X}$ water in the manuscript) during soaking (Table 1). Due to the high amount of FAN, a relatively small amount of this water would be required to be added to the wort, which would reduce the dilution (only $10 \%$ ). Further concentration (using less than 2.5 times water) was not possible due to insufficient water available to soak all of the germ. Germ (from yellow dent corn) was soaked in water (1:2.5 germ to water ratio, mass basis) and incubated at $52{ }^{\circ} \mathrm{C}$ for $12 \mathrm{~h}$ with continuous shaking at $125 \mathrm{rpm}$. In this experiment, $27 \mathrm{~mL}$ of this water was mixed in $265 \mathrm{~mL}$ wort, before the boiling step. The rest of the steps were similar to the previous process, as explained in Figure 1. In addition to the current treatment (adding $4 \mathrm{X}$ water in wort) and control (no germ water), another treatment (1X water) following the original process (adding germ water from 1:10 germ to water ratio to make corn mash) was also conducted for comparison purposes. To keep the wort concentrations similar in all three cases, $27 \mathrm{~mL}$ of deionized water was added in the wort before boiling for control and $1 \mathrm{X}$ water. All treatments were conducted in replication.

Figure 6 illustrates the ethanol production rate comparison for three cases: (i) control, (ii) use of germ soak water to make corn mash (1X water), (iii) use of concentrated (4X) germ soak water in the wort. The addition of concentrated germ soak water in wort increased the fermentation rate compared to the control. Both treatments (the addition of $4 \mathrm{X}$ water in wort or making corn slurry with germ water) were equally efficient in increasing the fermentation speed. The ethanol concentration was almost the same for both treatments at all the time points. Less than $0.1 \%(\mathrm{w} / \mathrm{v})$ maltose was observed after $96 \mathrm{~h}$ of fermentation, compared to $0.73 \%(\mathrm{w} / \mathrm{v})$ for the control, for which the maltose concentration was found to be $0.1 \%$ after $120 \mathrm{~h}$ of fermentation. The fermentation rate was $30 \%$ higher 
than the control between 48 and $72 \mathrm{~h}$ of fermentation. These results indicate that germ water can be concentrated and added to the wort to fasten the fermentation.

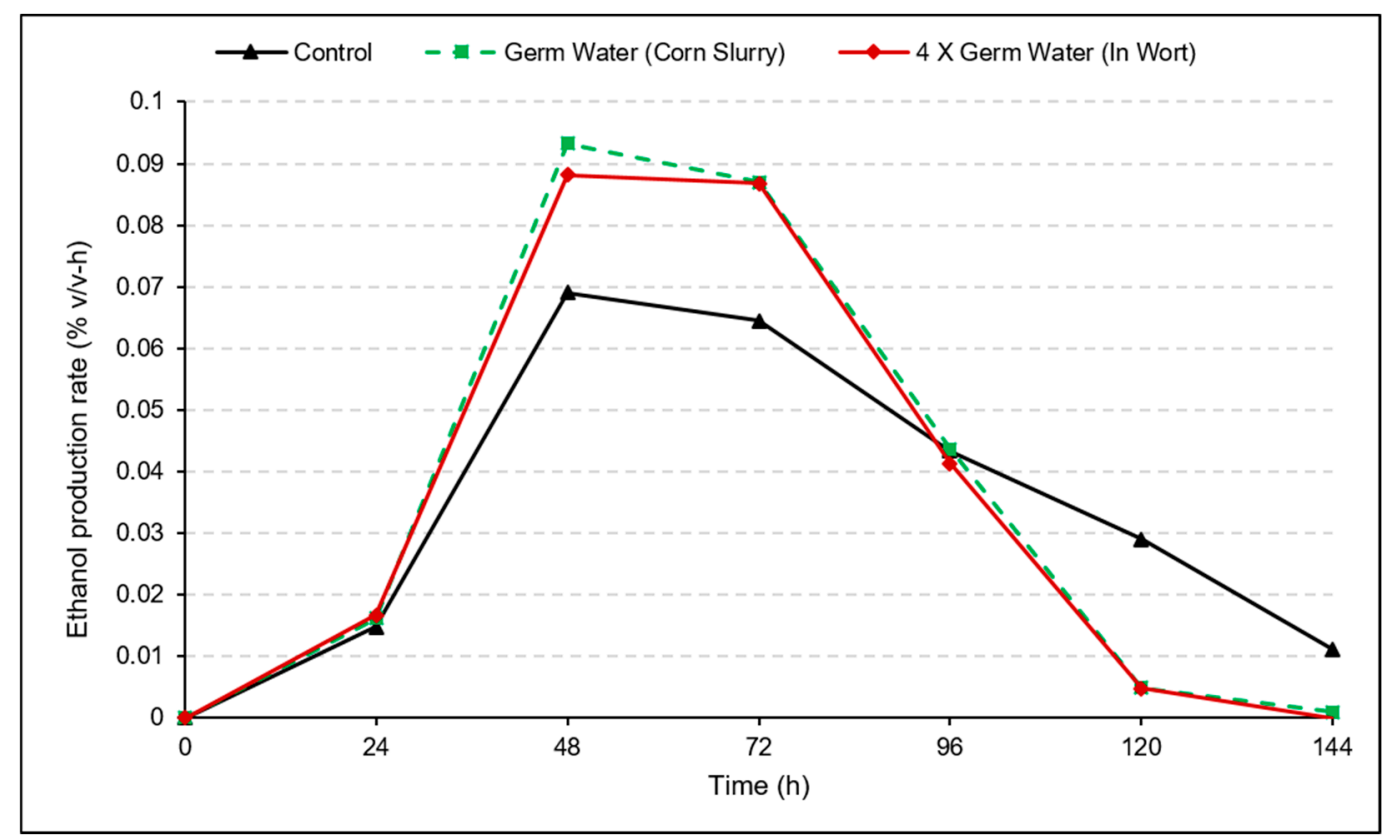

Figure 6. Rate of ethanol production during fermentation for three cases: (i) control, (ii) use of germ soak water in corn mash, (iii) use of concentrated germ soak water in wort. Data in the graphs is the average of two replications.

\subsection{Change in Composition of Germ}

Corn germ is valuable for its oil content, which directly decides its market value [26]. The extraction of soluble protein and other micronutrients during soaking would increase the oil content in germ and improve its economic value. The oil content of soaked dent corn germ increased by $33 \%$ ( $21.6 \%$ to $28.7 \%$, dry basis) compared to raw germ. The increase in oil content of flint corn germ was found to be $29 \%$. Due to increased oil content, the germ would have a higher market price, which could compensate the cost required for soaking and filtration to make germ soak water. The protein content in soaked dent corn germ $(14.7 \%)$ was $5 \%$ less compared to raw germ $(15.5 \%)$. This reduction in protein content further indicates that soluble proteins were extracted during germ soaking, which enhanced the yeast functioning and fermentation speed.

\section{Conclusions}

Due to low protein content, the use of high amounts of corn grits as adjuncts causes nutrient deficiency to yeast during fermentation and leads to sluggish fermentation. This work developed economical process strategies to improve the fermentation rate by providing these nutrients from cereal-based origin. Water obtained from the soaking of corn germ was used as a nutrient source to improve yeast performance during the brewing process using $40 \%$ corn grits as adjuncts. The addition of germ water improved the FAN levels in the wort, which enhanced yeast functioning and shortened the fermentation time from 120 to $96 \mathrm{~h}$. The water obtained from flint corn germ had higher amounts of FAN compared to dent corn germ, however, the total maltose consumption time was $96 \mathrm{~h}$ in both cases. The study also demonstrated that the nutrients can be concentrated up to 4 times by proportionally decreasing the degree of dilution during the soaking process, and the concentrated water can be added directly to the wort to improve fermentation speed. Soaking of germ increased oil content by $33 \%$ in the germ, improving its market value. 
Author Contributions: D.K. performed experiments, analyzed data, and wrote the manuscript. D.K., V.S., and A.-S.H. designed the study and reviewed results. B.J.G. helped with data analysis and the design of experiments. A.-S.H. and W.D. reviewed and edited the manuscript. All authors read and approved the manuscript.

Funding: Partial funding for this study was provided by Anheuser Busch InBev.

Conflicts of Interest: Some of the coauthors (Anna-Sophie Hager, Alberto Sun, Winok Debyser, Bruno Guagliano) are current and former employees of Anheuser Busch InBev. However, in this study a new process was developed and no Anheuser Bush InBev products or processes were evaluated or compared with any other company's products.

\section{References}

1. Li, Q.; Wang, J.; Liu, C. Beers. In Current Developments in Biotechnology and Bioengineering; Elsevier: New York, NY, USA, 2017; pp. 305-351. Available online: https://www.sciencedirect.com/book/9780444636669/ current-developments-in-biotechnology-and-bioengineering (accessed on 11 January 2019).

2. Bravi, E.; Sensidoni, M.; Floridi, S.; Perretti, G. Fatty Acids Composition Differences between Beers Made With All-Malt and Brewer's Corn Grits and Malt; Technical quarterly; Food and Agriculture Organization (FAO): Rome, Italy, 2009.

3. Zhuang, S.; Shetty, R.; Hansen, M.; Fromberg, A.; Hansen, P.B.; Hobley, T.J. Brewing with 100\% Unmalted Grains: Barley, Wheat, Oat and Rye. Eur. Food Res. Technol. 2017, 243, 447-454. [CrossRef]

4. Poreda, A.; Czarnik, A.; Zdaniewicz, M.; Jakubowski, M.; Antkiewicz, P. Corn grist adjunct-application and influence on the brewing process and beer quality. J. Inst. Brew. 2014, 120, 77-81. [CrossRef]

5. Bogdan, P.; Kordialik-Bogacka, E. Alternatives to malt in brewing. Trends Food Sci. Technol. 2017, 65, 1-9. [CrossRef]

6. Cooper, C.; Evans, D.; Yousif, A.; Metz, N.; Koutoulis, A. Comparison of the impact on the performance of small-scale mashing with different proportions of unmalted barley, Ondea Pro ${ }^{\circledR}$, malt and rice. J. Inst. Brew. 2016, 122, 218-227. [CrossRef]

7. USDA-NAAS. Grain Crushings and CoProducts Production 2017 Summary; United States Department of Agriculture: Washington, DC, USA, 2018.

8. Lekkas, C.; Stewart, G.; Hill, A.; Taidi, B.; Hodgson, J. The importance of free amino nitrogen in wort and beer. Tech. Q.-Master Brew. Assoc. Am. 2005, 42, 113.

9. Zembold-Gula, A.; Blazewicz, J.; Wojewodzka, K. Protein Compounds in Brewing Worts Produced with Addition of Naked Barley Grain; Zywnosc Nauka Technologia Jakosc (Poland); Food and Agriculture Organization (FAO): Rome, Italy, 2008.

10. Stewart, G.G.; Hill, A.E.; Russell, I. 125th anniversary review: Developments in brewing and distilling yeast strains. J. Inst. Brew. 2013, 119, 202-220. [CrossRef]

11. Yano, M.; Tsuda, H.; Imai, T.; Ogawa, Y.; Ohkochi, M. The effect of barley adjuncts on free amino nitrogen contents in wort. J. Inst. Brew. 2008, 114, 230-238. [CrossRef]

12. Murthy, G.S.; Singh, V.; Johnston, D.B.; Rausch, K.D.; Tumbleson, M. Improvement in fermentation characteristics of degermed ground corn by lipid supplementation. J. Ind. Microbiol. Biotechnol. 2006, 33, 655-660. [CrossRef] [PubMed]

13. Ramchandran, D.; Wang, P.; Dien, B.; Liu, W.; Cotta, M.A.; Singh, V. Improvement of Dry-Fractionation Ethanol Fermentation by Partial Germ Supplementation. Cereal Chem. 2015, 92, 218-223. [CrossRef]

14. Murthy, G.S.; Singh, V.; Johnston, D.B.; Rausch, K.D.; Tumbleson, M. Evaluation and strategies to improve fermentation characteristics of modified dry-grind corn processes. Cereal Chem. 2006, 83, 455-459. [CrossRef]

15. Juneja, A.; Kumar, D.; Singh, V. Germ soak water as nutrient source to improve fermentation of corn grits from modified corn dry grind process. Bioresour. Bioprocess. 2017, 4, 38. [CrossRef] [PubMed]

16. Rausch, K.D.; Pruiett, L.E.; Wang, P.; Xu, L.; Belyea, R.L.; Tumbleson, M. Laboratory Measurement of Yield and Composition of Dry-Milled Corn Fractions Using a Shortened, Single-Stage Tempering Procedure. Cereal Chem. 2009, 86, 434-438. [CrossRef]

17. Vidal, B.C., Jr.; Rausch, K.D.; Tumbleson, M.; Singh, V. Protease treatment to improve ethanol fermentation in modified dry grind corn processes. Cereal Chem. 2009, 86, 323-328. [CrossRef]

18. AOAC. Official Methods of the Association of Official Analytical Chemists Washington, DC; Vol. Methods 920.39, 924.05, 973.18, 990.03; AOAC: Rockville, MD, USA, 2003. 
19. Vidal, B.C., Jr.; Johnston, D.B.; Rausch, K.D.; Tumbleson, M.; Singh, V. Germ-derived FAN as nitrogen source for corn endosperm fermentation. Cereal Chem. 2011, 88, 328-332. [CrossRef]

20. AOAC. Official Methods of Analysis of AOAC International: Arlington, VA.; Vol. Method $982.30 \mathrm{E}(\mathrm{a}, \mathrm{b}, \mathrm{c}) \mathrm{chp}$. 45.3.05; AOAC: Rockville, MD, USA, 2006.

21. Lekkas, C.; Stewart, G.; Hill, A.; Taidi, B.; Hodgson, J. Elucidation of the role of nitrogenous wort components in yeast fermentation. J. Inst. Brew. 2007, 113, 3-8. [CrossRef]

22. Rowell, J.L. Exploring Fermentation Rate in Beer and Hard Cider Brewing; Western Carolina University: Cullowhee, NC, USA, 2015.

23. Walker, G.M. Metals in yeast fermentation processes. Adv. Appl. Microbiol. 2004, 54, 197-230. [PubMed]

24. De Nicola, R.; Walker, G.M. Accumulation and cellular distribution of zinc by brewing yeast. Enzyme Microb. Technol. 2009, 44, 210-216. [CrossRef]

25. Bromberg, S.K.; Bower, P.A.; Duncombe, G.; Fehring, J.; Gerber, L.; Lau, V.K.; Tata, M. Requirements for zinc, manganese, calcium, and magnesium in wort. J. Am. Soc. Brew. Chem. 1997, 55, 123-128. [CrossRef]

26. Johnston, D.B.; McAloon, A.J.; Moreau, R.A.; Hicks, K.B.; Singh, V. Composition and economic comparison of germ fractions from modified corn processing technologies. J. Am. Oil Chem. Soc. 2005, 82, 603-608. [CrossRef]

(C) 2019 by the authors. Licensee MDPI, Basel, Switzerland. This article is an open access article distributed under the terms and conditions of the Creative Commons Attribution (CC BY) license (http:/ / creativecommons.org/licenses/by/4.0/). 